\title{
807 ボタン押し音評価の検討 \\ A study of evaluating the button sounds
}

\begin{abstract}
正○石光 俊介（広島市立大）准 阪本 浩二（兵庫県立大） 学 荒井 貴行（兵庫県立大）
非 好美 敏和 (パイオニア) 非 藤本裕一（パイオニア）非川㥓健一（パイオニア）
\end{abstract}

Shunsuke ISHIMITSU, Hiroshima City University,

3-4-1, Ozuka-Higasi, Asa-Minami, Hiroshima, 731-3194 JAPAN

Koji SAKAMOTO, Takayuki ARAI, University of Hyogo

Toshikazu YOSHIMI, Yuichi FUJIMOTO and Kenichi KAWASAKI, Pioneer Corpration

Keywords: Wavelet Transform, Button Sounds, SD Method, Adaptive Control

\section{1 はじめに}

近年，自動車加速音など，騒音として扱われていた様々 な音を設計するサウンドデザインが注目されている(1) (3) 音も製品の一部という考え方が浸透してきたためである。

本研究ではカーオーディオ・メインユニットのスイッチ ボタン 11 種類の押し音のサウンドデザインとその評価に ついて検討を行った．まず，SD 法により印象を抽出し， それらの因子と時間周波数解析との関連性を調査した。 た，ボタン音の加工性を検証するため，印象の悪かったボ タン押し音の特性を印象の良かったボタン押し音に適応制 御で加工することにより印象が変化することも確認した。 一方，音は視覚，触覚の影響を受けることが知られている (4)，(5). そこで触覚についても解析を行い，聴感印象および 時間周波数解析との関連性について調查した.

\section{2 時間周波数解析}

\section{1 実験条件}

評価対象は 6 機種のカーオーディオ・メインユニットの ボタン 11 種類である。データ収録は無響室で行なった。 各ボタンを 3 回ずつ押し，メインユニットから $30 \mathrm{~cm}$ 離れ た位置でマイクによりその音を収録した。

\section{2 解析条件および結果}

図 1〜6にメインユニット別の WT 結果を示す．左か ら順に DFT 結果, プッシュ音, バック音の WT(Wavelet Transform) 結果を示す.「好き一嫌い」において高得点の ボタン音は低域にパワーが集中し，得点が低くなるほど高 域にパワーが集中する傾向を観測できた。 また．エネルギ の継続時間も関連していることが観測できた。
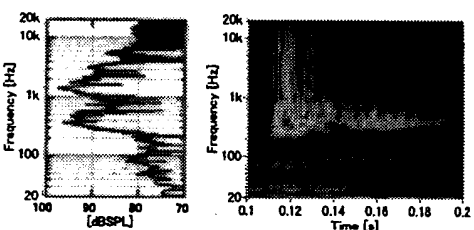

(a) ボタン
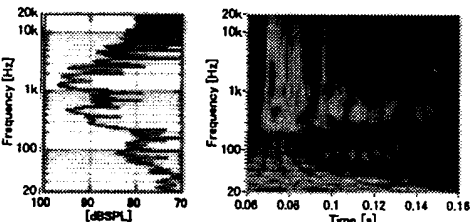

(b) ボタン

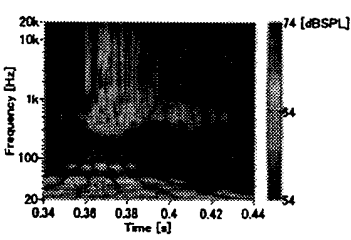

(1)

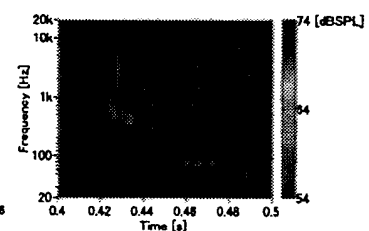

(2)
Fig. 1 メインユニット1の DFT およびWTによる振幅 特性；（左）Push 音と Back 音の DFT，（中）Push 音の WT，（右）Back 音の WT
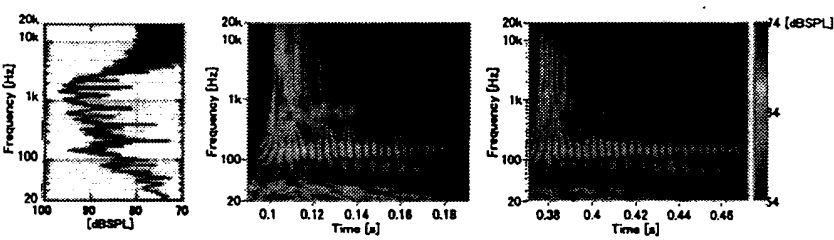

(c) ボタン
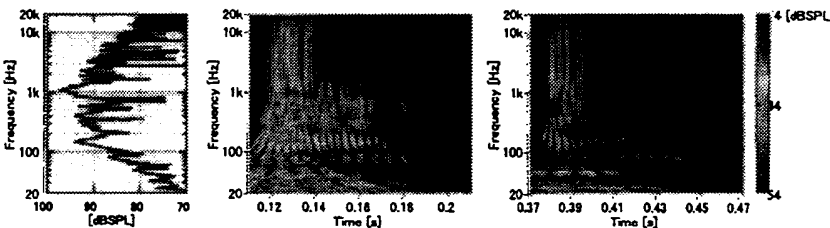

(d) ボタン (4)

Fig. 2 メインユニット 2 の振幅特性; (左) Push 音と Back 音の DFT, (中) Push 音の WT，(右) Back 音の WT
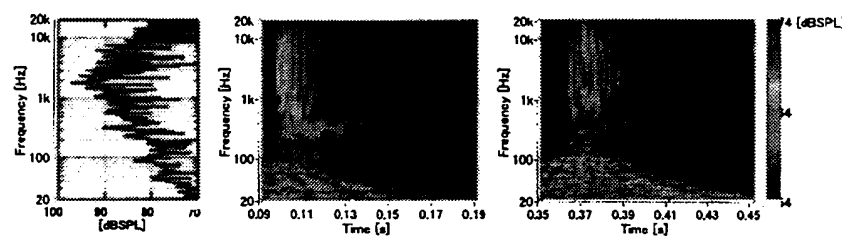

(e) ボタン

(5)

Fig. 3 メインユニット 3 の振幅特性; (左) Push 音と Back 音の DFT，(中) Push 音の WT，(右) Back 音の WT

\section{3 聴感評価}

実験は健聴者 67 名に対して SD 法により行ない, ヘッ ドホンにより音を再生した。この実験結果の因子分析を行 い, WT との対応付けを試みた。求めた因子負荷量と因子 得点をそれぞれ表 1 ，図７に示す，第 1 因子から順に金属 性因子，美的因子，迫力因子と解釈し，それぞれ得点が高 いほど「硬い，「心地よい」，「迫力のある」音であること がわかる，図７より，「好きな」ボタン音は金属性因子，迫 力因子の得点が低く，美的因子の得点が高いことがわかっ た。 また「嫌いな」ボタン音はそれぞれの因子得点が逆転 することがわかった。このことは図 1〜6のWTの結果と 対応している.

また，感触評価実験も同様に行った。第 1 因子から順に 心地良さ因子，強さ因子と解釈し，それぞれ得点が高いほ ど「心地よい,「強い」感触であった。「好きな」ボタン は心地良さ因子の得点は高くなるが，強さ因子には奇与し ないことがわかった，音のWTとの対応付けを行なった結 果，パワーが低域に集中するボタンは心地良さ因子の得点 が高い傾向となった。 

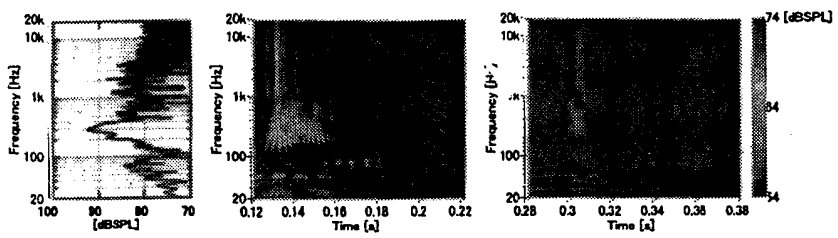

(f) ボタン $(6)$
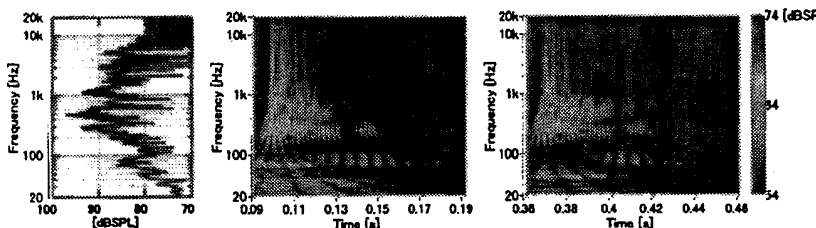

(g) ボタン (7)
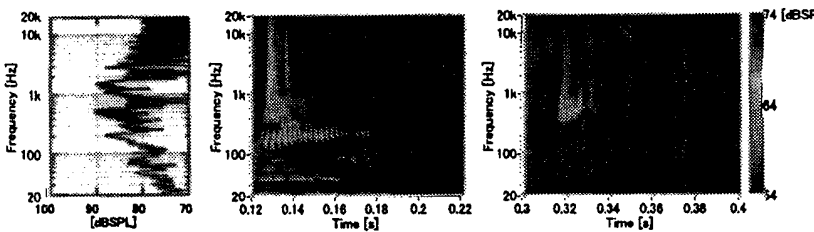

(h) ボタン (8)

Fig. 4 メインユニット 4 の振幅特性 ; (左) Push 音と Back 音の DFT, (中) Push 音の WT, (右) Back 音の WT
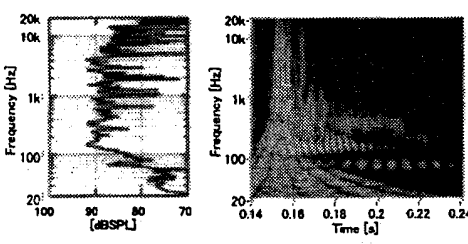

(i) ボタン (9)

Fig. 5 メインユニット 5 の振幅特性 ; (左) Push 音と Back 音の DFT，(中) Push 音の WT，(右) Back 音の WT
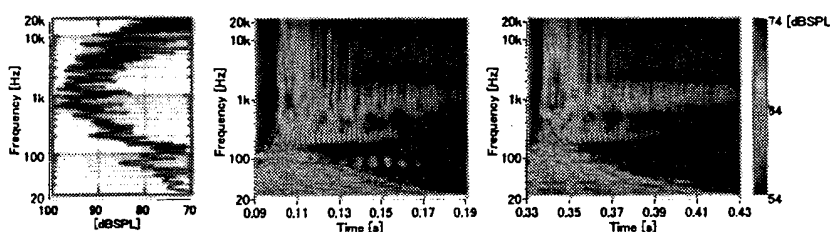

(j) ボタン (10)
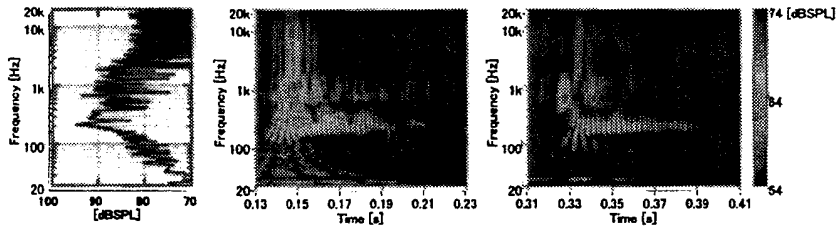

(k) ボタン (11)

Fig. 6 メインユニット 6 の振幅特性; (左) Push 音と Back 音の DFT，(中） Push 音の WT，(右) Back 音の WT

\section{4 音筫制御}

最も印象の悪かったボタン (10)を最も印象の良かった ボタン音 (6) へ近づくように適応制御を行ない，印象を調 查した. WT 解析結果を図 8 に示す。これは”好き”に分 類されたボタン音に近い聴感印象であった.
Table 1 因子負荷量

\begin{tabular}{|c|c|c|c|c|}
\hline & 金屈性因子 & 类的因子 & 迫力因子 & 共通性 \\
\hline 硬い/柔らかい & 0.91 & -0.20 & 0.33 & 0.97 \\
\hline はっきりしたノほやけた & 0.90 & -0.10 & 0.41 & 0.98 \\
\hline 高い/低い & 0.86 & -0.39 & -0.01 & 0.90 \\
\hline 地味な/派手な & -0.63 & 0.52 & -0.46 & 0.88 \\
\hline 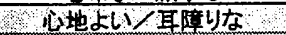 & -0.22 & 0.95 & -0.14 & 0.96 \\
\hline 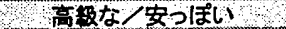 & -0.36 & 0.91 & 0.12 & 0.96 \\
\hline クきめ紐かい/粗い & -0.09 & 0.88 & -0.42 & 0.95 \\
\hline 迫力のある/もの足りない & 0.15 & -0.02 & 0.95 & 0.92 \\
\hline 強い/弱い & 0.65 & -0.20 & 0.74 & 1.00 \\
\hline 大きい/小さい & 0.50 & -0.45 & 0.71 & 0.95 \\
\hline 因子寄与率 & 36.41 & 32.02 & 26.48 & 94.90 \\
\hline
\end{tabular}

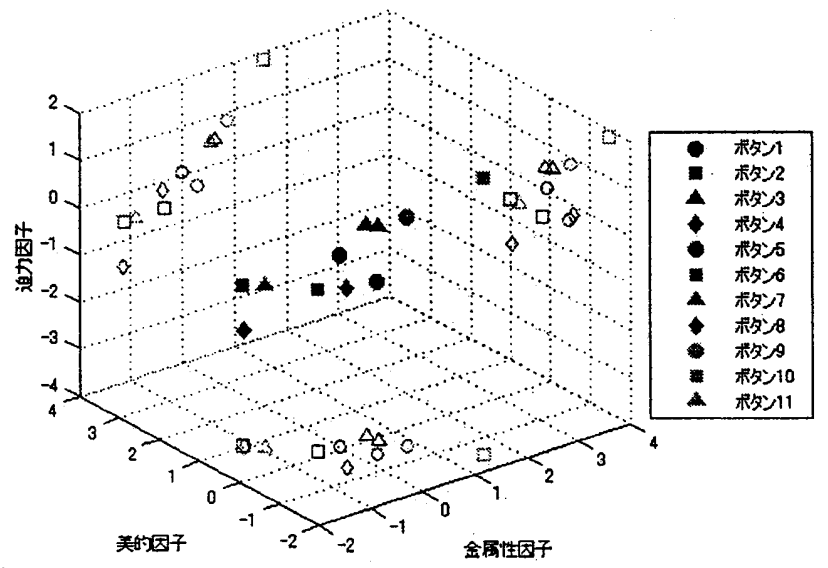

Fig. 7 因子得点

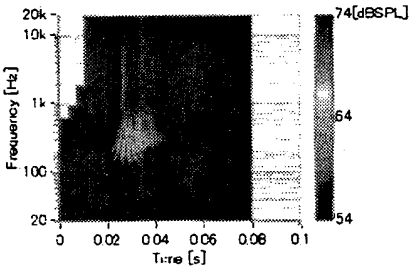

(a) 適応後のボタン音 $(10)$

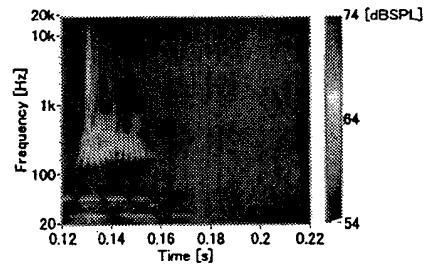

(b) ボタン音 (6)
Fig. 8 信号処理後のボタン音 (10) とボタン音 (6) のWT の比較

\section{5 結言}

本研究ではボタン押し音のサウンドデザインとその評価 について検討を行った。 WT 特性と聴感印象を対応付けた 結果, 低周波数のボタン音は好印象であり高周波数のボタ ン音は印象が悪く，両者とも金属性，美的，迫力因子に印 象が分類されることがわかった．また，印象の悪かったボ タン押し音の特性を適応制御で加工することにより印象が 変化することも確認した。 今後，これらの知見がスイッチ 音サウンドデザインに活かされることが期待される.

\section{参考文献}

(1) 石光, 小林、機論, Vol. 72, No. 719, C, pp.2094-2100, 2006

(2) 戸井，機械設計, Vol. 48, No. 2, pp.36-45, Feb., 2004

(3) 桑野,“音環境デザイン”, コロナ社, 2007

(4) L. Shams et al., Nature, 408, pp. 788, 2000.

(5) H. Gillmeister et al., Brain Res, 1160, pp.58-68, 2007 